\title{
Special Education Teachers Life Stories: Subjectivity and Education
}

\author{
Marlene Rozek ${ }^{1}$, Claus Dieter Stobäus ${ }^{2 *}$ \\ ${ }^{1}$ Postgraduate Program in Education, Pontifical Catholic University of Rio Grande do Sul, Porto Alegre, Brazil \\ ${ }^{2}$ Postgraduate Program in Education and in Biomedical Gerontology, Pontifical Catholic University of Rio Grande do Sul, Porto \\ Alegre, Brazil \\ Email: *stobaus@pucrs.br
}

How to cite this paper: Rozek, M., \& Stobäus, C. D. (2017). Special Education Teachers Life Stories: Subjectivity and Education. Creative Education, 8, 1957-1967. https://doi.org/10.4236/ce.2017.812133

Received: June 6, 2017

Accepted: September 25, 2017

Published: September 28, 2017

Copyright (C) 2017 by authors and Scientific Research Publishing Inc. This work is licensed under the Creative Commons Attribution International License (CC BY 4.0).

http://creativecommons.org/licenses/by/4.0/ (c) (†) Open Access

\begin{abstract}
This article is about study of subjectivity and the teacher education process of students with special needs, intending to understand the movements and paths of the personal and professional formation process of the subject-teacher, as well as the productions of meaning that configure teaching with students who present a diagnosis of special needs, as intellectual deficiency and/or multiple deficiency, associated or not with psychic disorders. Considering that human subjectivity is characterized by the production of meanings, the present study points to the understanding of the subjective senses attributed to the different experiences lived in the context of teaching with students with disabilities. It was intended to produce, through the understanding, analysis and argumentation, effects of meaning that make it possible to advance the understanding of the complex field of teacher education in Inclusive Education. The research was based on the Narrative-Life Stories approach of two teachers of the State Public School System of Porto Alegre-RS city, with a long teaching experience in Special Education, whose biographic trajectories were interpreted in the light of the philosophical hermeneutics of Hans-Georg Gadamer. That is, we sought to understand the discursive horizons that constitute the teacher of students with disabilities and, thus, life stories were understood from four categories: dialogue, otherness, experience and the construction of oneself. They seek to discuss the horizons they demarcate and constitute the training path of the teachers. In this way, it becomes possible to think philosophically the teacher's formation, seeking to give a singular look/sense to the concept of formation, because it is considered fundamental to understand how the subject-teacher is constructing and configuring his existence as a teacher of students with disabilities. This understanding of teaching as a relationship experience can allow the quest for the know-how to live with oneself and with the other.
\end{abstract}




\section{Keywords}

Special Education, Teacher Education, Subjectivity, Life stories

\section{Introduction}

Gadamer refers us to a universe in which hermeneutics refers to the world from experience, to the world of pre-comprehension in which we already are and understand ourselves. As beings from the previous structure of meaning, understanding, therefore, is linked to the context of life and the human. The very act of understanding is an existential reality. Hermeneutic understanding indicates that education presupposes openness to the other, with history and language as the structuring elements of our access to the world (Hermann, 2002). History and language are the fields of excellence in which one perceives the pre-reflective horizon found at the base of all human action.

Gadamerian thought allows or even promotes the emergence of a hermeneutic in which the interpretive process does not stem from the discovery of the exact or correct sense of a text, but from the analysis of the conditions in which understanding occurs. In this way, the elements that make up a hermeneutic path can be, according to Santos (1989):

1) the clarity that understanding a research phenomenon means launching a listening and a look, from a moving point;

2) the understanding that an absolute truth ceases to have meaning, since knowledge carries in itself the mark of its provisional nature, scientific knowledge being understood as a movement of re-elaboration, deconstruction and rectification; and

3) truth is considered a provisional result, which implies negotiation of meanings in a scientific community, and truth is the convincing effect of the various real discourses.

It is in this understanding horizon that this research finds itself. It was intended to produce, through the understanding, analysis and argumentation, effects of meaning that make it possible to advance in the studies on the complex field of teacher education. In this sense, the investigative stance follows a hermeneutical path based on a work of understanding and interpretation of the phenomenon in question. In a hermeneutical perspective, the search for truth is linked to the dialogue of the researcher with the text, whose senses are understood in their historical dimension, in a constant negotiation of meanings, through the language. This requires an interpretive opening about what the texts of the narratives of the teachers participating in this study say, which they seek to show, to legitimize. In the understanding movement, the researcher/interpreter's position is to open the dialogue with the texts, seeking to understand them in their claim to truth, seeking to establish a listening from their understanding horizons. 


\section{Gadamer (2007: 145) says that:}

"Whoever wants to understand a text, is willing to let the text tell you something. Therefore, a consciousness formed hermeneutically must be willing to accept the otherness of the text. But such receptivity does not suppose neutrality, nor self-censorship, but implies the selective appropriation of one's opinions and prejudices. One must guard against one's own prejudices so that the text itself appears in its otherness and asserts its real truth against the interpreter's own opinion."

In a hermeneutical situation, it is sought to understand the discursive horizons that represent the teacher of students with disabilities. However, we do not start from categories built a priori, but we seek to project on the narratives, anticipations of meanings that were being re-signified in the measure in which our understanding advanced. In this process, one can perceive that the meanings of a text surpass its author and that the understanding can't be considered a reproductive behavior, since the main characteristic of the understanding is precisely the process of continuous production of meanings. Understanding does not necessarily mean knowing more, in the objective sense, but it means the force of the argument present in the texts and the possibility of dialogue.

For Gadamer (2007), comprehensive reading is not the repetition of something past, but participation in a present sense and, in this perspective, we sought to understand the texts/narratives in the actuality of what they say and what they are silent, trying to experience an effective participation in what the Texts communicate. Thus, interpreting a text means translating it to the present moment, seeking in it the arguments for the questions of the current context, considering that the interpretative process does not refer to the author's individuality and intentions, but to the truth claim formed in the text itself interpreted. In this way, our hermeneutic attitude was given in the projection on the discursive horizons present in the texts of the narratives, trying to understand them in their pretension of truth. It should be emphasized that these axes should not be understood as the only and correct truth present in the texts, but as an interpretation supported by the theoretical contributions of this study.

Gadamer (2007: 575-576) contributed saying that:

"The texts do not want to be understood as a vital expression of the author's subjectivity. Consequently, it is not from there that the limits of its meaning can be traced [...]. What is fixed in writing has got rid of the contingency of its origin and its author and has liberated itself positively for new references. Normative concepts such as the author's opinion or the understanding of the original reader do not represent, in reality, more than an empty place that fills in the comprehension."

Thus, through the hermeneutic mode of understanding, we think it is possible to account for the guiding questions of this study, since "hermeneutics shows the impossibility of reducing the experience of truth to a methodical application because truth is immersed in the dynamics of time" (Hermann, 2002: 15).

We then examine the axes of interpretive analysis. 


\section{Dialogue}

For Gadamer, the human experience of understanding cannot be observed by the molds of an instrumental procedure, however, the strong refusal of the method does not prevent the author from treating hermeneutics as a peculiar procedure, because is composed of dialogue (Dalbosco, 2006: 358), and the understanding, in this perspective, "only can be learned as a human procedure constituted by language which manifests itself through dialogue (Gespräch) and the living word". A direct link between method and dialogue is perceived, however, contrary To the connection to the positivist sense, between method and technique.

Contemporary societies marked and oriented by the predominance of instrumental reason, in which technical concepts and practices prevail, fail to perceive the fruits of human interactions. Gadamer associates this characteristic of the contemporary world-the incapacity for dialogue-to the technical-scientific development. This inability to dialogue forms an important impediment to pedagogical action, since the whole educational process occurs in the interactions between and with the subjects. Dialogue can't exist between subjects who can't take an attitude of listening.

Gadamerian thinking helps us to perceive the inability to dialogue beyond the walls of the school institution, that is, as an almost generalized tendency of the contemporary world, involving people, institutions, groups and so many other segments of society. It is in this context that dialogue needs to be rescued as the central axis of the human sciences and of Pedagogy itself.

The modern world has built resources that enable the knowledge through different means, however, one must have the discernment that these means do not dispense with the need for interactions, because they bring with them the technical concepts, such as efficiency and competitiveness. In general, the educational field became a resource space and procedural techniques, moving away from a theoretical-reflexive rationality, starting to act based on common sense, impoverishing the training process of its subjects. In the absence of reflection, the school institution closes itself to dialogue, either with the systematized theories or with its peers in the educational context.

Human dialogue implies a relationship of subjects who share the word, with the possibility of listening, because without it dialogue is not effective. The dialogue presupposes the existence of knowledge that is not absolute, making the subject perceive himself unfinished and recognizing that the other is capable of possessing different knowledge. The presence of authentic dialogue in the educational process is of fundamental importance, as well as fostering more fraternal bonds, leads to an understanding of the existential horizon of the other.

According Hermann (2002: 95), dialogue, because it is not a methodological procedure, is organized in the very power of educating and teaching, in the sense of a constant confrontation with oneself, with their opinions and beliefs, and these dialogue leads to the opening of horizons, which "enables education to as- 
sert the polysemy of discourses and create a space for mutual understanding between those involved".

Thus, in the educational field, there is a need to recognize dialogue as mediating element of practices and pedagogical relationships that are more inclusive and humanizing. Difficulties have been found in establishing, in dialogue, a more comprehensive understanding of the other.

In the field of Inclusive Education, in its different spaces, dialogue must find its place in the pedagogical relationship and also in the relations between the subjects that make up the educational scene as a whole, because of the difficulty in dialoguing with the other, the human being It loses the intrinsic problematizing character of dialogue and with it the possibility of understanding the horizon of the other.

The pedagogical action requires an interaction focused on the dialogical formation of the subjects that compose this process, because together with the lived dialogue, lies the capacity to seek the encounter with the other, to want to listen to it and, with that, to understand it. In this sense, pedagogical action can be understood as a lived dialogue, a processual movement that builds its own internal dynamics, far from a mechanical and meaningless doing, indifferent to the needs of the other. Thus, in the process of constructing knowledge, something becomes understood insofar as the subject seeking understanding is able to hear the other, to establish a relationship of otherness in an authentic dialogical encounter, in which we are no longer the same, because we have become this relationship.

\section{Alterity}

Scientific development has brought to the contemporary world splendid achievements, provoking important effects in different areas. With this, the human being had its consciousness expanded and the formal education began to be valued, becoming accessible to a greater number of people. However, the knowledge developed by science itself has also amplified the contradictions inherent in the human way of living and living together.

Gadamer teaches us that knowledge is a construction of experience, hermeneutically structured, in which truth is manifold, historically localized and linked to the context in which knowledge is given. Knowledge is hermeneutically constructed from the phenomenon with which the knower comes in contact and not a simple representation or copy of the real, which requires a continuous interaction.

When we believe that what we know does not reveal essences but are human constructions, it becomes possible to develop an open and favorable subjectivity to the acceptance of the other, with his particular way of being, of living and the satisfaction of being by his side. Thus, the other is conceived as a source of wealth, previously unknown.

We live in a world that can only exist if we create it with the other. The accep- 
tance of the other becomes an ontological condition for us to exist as humans. Therefore, it is considered necessary that the subject-teacher develops a subjectivity open to the differences and specificities of the other, in this study, the student with deficiencies. In this way, this other is seen no longer as a threat, but as a source of wealth, precisely because it has a truth different from mine. Thus, in Gadamer's hermeneutics, a relation of otherness is perceived, where we are invited to rethink our position in front of the other.

For Trevisan (2006) otherness can be understood as a necessary counterpoint to the idea of identity, approaching how we can include the other, without making it the same, promoting inclusion without homogenization, respecting the other in its infinite diversity.

In Truth and Method II (Gadamer, 2002), we perceive a culture of alterity as opposed to the valorization of language and tradition as instances that allow the interpretive possibilities in the face of the emergence of the different and the new.

For Gadamer (2007), the conservation and non-suppression of the otherness of the other in the understanding actis the commitment of hermeneutics. It is the other, being different, differentiated or deficient, that causes strangeness, leading to the need to understand. To this end, and proposes dialogue as an indispensable element for the production of alterity in the field of knowledge. His hermeneutics is identified with the otherness present in language and traditions, since it recognizes and considers the other in the understanding act.

It is understood that openness to the other is a fundamental element in the recognition of the need for a process of humanization.

\section{Experience}

The human being, marked by tradition, has always been experienced at the heart of a world of meaning. For Gadamer (2007), historicity is an inherent condition of human experience, which presupposes an openness to experience it, in alterity with the world, with the other and with tradition. Fundamentally, experience is thus the experience of historicity itself.

The hermeneutic experience is effective between subjects, mediated by tradition and language. In the context of this study, teachers' narratives are understood as an individually narrated experience, however, socially shared; Are self-interpretive narratives, that is, teachers are considered interpreters of their own biographical path.

Understanding the teaching experience with students with disabilities requires the teacher as interpreter of their context, while being interpreted subject. It means, in a Gadamerian perspective, that the subject and the meaning of the world are organized in the dialectic of understanding and interpretation. The subject is facing a text-world, inserted in the polysemic adventure of producing meanings, from its historical horizon.

The daily school life is, above all, a space-time of teaching organization, an 
experience that can only be understood together with the set of circumstances that makes it possible, considering the life stories of the teachers in interaction with reality. Therefore, to think of teacher education as an experience of relationship implies an attentive and sensitive listening to life stories and the search for understanding of the multiple movements that make teaching an experience in the Gadamerian sense, considering that our experience of the world is fundamentally Interpretive (Hermann, 2002).

\section{Self-Construction}

In the process of self-knowledge, it is important not only to understand how we are formed through a set of lifelong experiences, but to be aware that the recognition of oneself allows the subject, pointed (Josso, 2004: 58):

"[...] to look at their life itinerary, their investments and their objectives on the basis of a possible self-direction, which articulates their heritage, their formative experiences, their social groups in a more conscious way, Their valuations, their desires and their imaginary in socio-cultural opportunities."

This process presents itself as a project of knowing what we are, think, do, value and desire in our relationship with ourselves, with others and with the human and natural environment (Josso, 2004). This knowledge of itself seeks to apprehend the complex imbrications of existence, as well as the different ways of being in the world and of putting ourselves in it.

The process of knowing oneself requires a responsibility of the subject before its existence and the existence of others. In the process of self-knowledge a subject comes into play who becomes an author in thinking of his existentiality, a subject who guides the continuation of his history with awareness of his resources and fragilities, his representations and valuations, his expectations and desires.

The self-reflexive process, which requires a retrospective and prospective look, has to be understood as an activity of critical self-interpretation and awareness of the social, historical, and cultural relativity of the referents internalized by the subject and, therefore, constitutive Of the cognitive dimension of subjectivity (Josso, 2004).

This interpretive work of oneself develops in the confrontation with the gaze of the other, with all the contrasting effects that this confrontation generates. This movement brings the impossibility of existence independently of others as well as the desire for existence, in spite of others. This allows us to recognize the other's place as revealing of myself. This other one that welcomes my difference and that, also, the threat.

The existential singularity occurs in a dialectical movement between the interiority (what is lived and thought within) and exteriority (what is social, historical and cultural), the way of living and assigning meaning or projecting socio cultural markers and successive images throughout life. In this movement, between an inner and/or outer event, an attribution of meaning occurs that can 
establish the experience itself.

In the plurality of feelings that represent and cross human existence, there is one that demands special attention, taking into account the sovereign place that occupies in our lives and the role that plays when the construction of itself brings together the search for meaning and the very desire of be happy. I am referring to love, given and received under its different forms of manifestation: loving feeling, filial love, passion, friendship, camaraderie, solicitude, in short, all forms of attachment or relationship that a person considers affectively significant.

We know that one of the challenges of self-construction is crossed by our ability to love ourselves, not in the narcissistic sense of the term, but in the perspective of our ability to maintain a mediated relationship of trust in ourselves that allows, in a single time, to accept ourselves as we are and to participate in processes of change and growth.

The search for the self and the nodes is given by the different choices in the course of life, whether in the friendships of childhood, in the group of affinities, in the search for a companion or companion, in the formation of a family, in the search for another nationality, In other words, itineraries that express different interests, in the perspective of the different senses that we are attributing to our lives.

The search for meaning presents itself as a central principle in the art of living; Is a search that demands a reflexive commitment in individual and collective practices that explore attitudes and behaviors. The quest for existentiality (Josso, 2004) is full of solidarity and lucidity of perceiving and understanding the turbulences of the human condition as well as the fragility of being in the world.

Considering a course, we understand that biographical work on itself, besides giving meaning, helps us to discover and understand the origin of what we are; Constitutes a formative experience, in the words of Josso, because we make use of fragments more or less elaborate and complex of the socio-anthropological heritage that we bring.

For Gadamer (2007: 57), the fundamental characteristic of training is "to remain open to the different, to other universal points of view". The points of view are not a fixed standard, but are present only as points of view of possible others.

Amplifying the idea of a better teacher education, from an inclusive education perspective, whether initial or continuing, requires a deep study and reflection on the bases that justify it; Needs axes that integrate the pedagogical, philosophical, anthropological and historical fields. It means that the subject-teacher needs the understanding of the meaning of his existence and his profession, due to his belonging to the human species, his insertion in a certain society, with its ties and peculiarities, as well as the resources of human knowledge in Construction of all these references.

In the direction of better deal with students with special needs, we emphasizes that we perceive (Rozek \& Stobäus, 2016: 2706): 
"[...] a pedagogical approach that assumes a conception of being in the world in constant relation, a socio-historical construction. The learning implies a $d y$ namic relationship of the subject in the social context; all learning is linked to very specific meanings for each subject entered in the subjectivity of each through the movements of time and history. This exchange with the context and the affections causes emotions and also emotional problems. These interact with cognition, affect the relationship with the teacher, family and can cause a blockage in learning. Therefore, it requires not learning of the school, a discussion movement and intervention in their databases, and requires learning about their own practices."

In these directions, we can also alert that in the teachers' education (Teixeira, Mosquera, \& Stobäus, 2015: 1051):

"[...] there is a need to work better concepts and conceptions that teachers demonstrate in order to promote practices consistent with theories that use. Basic continued training must be for better quality, also specific monitoring and monitored training. We should use aid and support should be available all the time, in working with multidisciplinary and interdisciplinary teams, with professionals in areas such as Education, Psychology and Health. There are difficulties: times and rhythms are not the same at school, at home with parents and do not violate society's satisfactions: the small changes in the school, at home, extensively to a more prepared society, we should still take care in teaching rhythms and individual difficulties in learning to remember that slight changes are important. The education of teachers should take into account continuity and updating, taking into account new paradigmatic concepts and lines of research on Inclusive Education, deepening in multidiversidade studies, especially with regard to the differences, and the approach with professionals from other fields."

As we said (Rozek \& Stobäus, 2016: 1953):

"The hermeneutic perspective in understanding the teaching shows it is relevant because it allows the construction of interpretive horizons about himself and the others, which allows broader understanding of human interpersonal relationships and own educational act. It is also important to remember and reflect on the influences of other topics, such as knowledge and skills of teachers who work in Special/Inclusive Education, including the concepts they use and how they see that it operates, as well as affectivity and healthier interpersonal relationships."

In other words (Rozek \& Stobäus, 2016: 1959):

"Teachers' education must be also considered as a 'hermeneutic relationship', just as a way of productive relationships, better if it is in the interpersonal relationships (preparation in the teacher-student, observing student-student, or also student-parents-society)."

Also, in our perspective of teaching, especially in Special Education/Full Inclusion, there is a necessity to recognize the:

"[...] importance of understanding the role of emotional processes in the de- 
velopment of learning disabilities. In addition, it is necessary to reflect on teacher education that problematizes this issues. Education should not be limited to the ownership of a technical instrumental that offers a recipe for efficiency."

Prepare someone to be a professional, in the different areas, require much preparation in knowledge, also a lot of skills and attitudes. But, when we are speaking about teacher education, we must think also in other directions, as intrapersonal and interpersonal development, so as better relationships with pears, students, their parents, all the represented society. Remembering that the teacher is an example of caregiver, a model to their students and the society.

\section{Conclusion}

The teacher education is a central issue for the area of Education when it is understood that the core of the educational process lies in the interactions that are established in the movements and processes of teaching and learning and which, in essence, bring a relationship between human beings; Therefore, a relation of ethics. Thus, it is also, by ethical requirement that the formation of the teacher must be conceived and realized; Investment in training and professional activity can't be reduced to a technical and methodological qualification.

In this sense, we understand that it is possible to think philosophically the teacher's formation from the reflections proposed by Gadamer, since the intention is to give another look/sense to the concept of formation. The issue that arises is not that subject's form, but how the subject-teacher is building their understanding of the world and configuring their existence as teacher of students with disabilities.

At this historical moment, where the main threat is homogenization, it may be possible to create the conditions for the plurality of meanings in the field of teacher education in the perspective of Inclusive Education. I am referring to the necessary reflection on the foundations underlying Education and teacher training, since social plurality requires a teacher formation guided by the bias of dialogue, otherness, the value of human experience and the construction of oneself.

To educate is to impregnate the life of meaning, is to make the being in the world a permanent process of humanization that is only possible in the coexistence with others. It is not only a matter of being together with the other, but being together and, in this sense, we need to create in ourselves with the material available for this creation. This material is given by the other, and this creation depends on the other as experience of otherness.

\section{References}

Dalbosco, C. (2006). Racionalidade e formação. [Rationality and Training]. In: A. A. Fávero, C. Dalbosco, \& T. Marcon (Eds.), Sobre Filosofia e Educação: racionalidade e tolerância [About Philosophy and Education: Rationality and Tolerance] (pp. 251-266). PassoFundo: Editora da UPF.

Gadamer, H.-G. (2002). Verdade e método II. Complementos e Índice. [Truth and Me- 
thod II. Add-ons and Index] (2 ed.). Petrópolis: Vozes.

Gadamer, H.-G. (2007). Verdade e método I: Traços fundamentais de umahermenêutica filosófica. [Truth and Method I: Fundamental Traits of a Philosophical Hermeneutics] (8 ed.). Petrópolis: Vozes.

Hermann, N. (2002). Hermenêutica e Educação. [Hermeneutics and Education]. Rio de Janeiro: DPA.

Josso, M. C. (2004). Experiências de vida e formação. [Life Experiences and Formation]. São Paulo: Cortez.

Rozek, M., \& Stobäus, C. D. (2016). Contributions of Gadamer to the Teachers Education in the Perspective of Full/Inclusive Education. Creative Education, 14, 1953-1960. https://doi.org/10.4236/ce.2016.714197

Rozek, M., \& Stobäus, C. D. (2016). Teachers Dealing with Learning Difficulties during the Process of Schooling. Creative Education, 17, 2696-2709. https://doi.org/10.4236/ce.2016.717252

Santos, B. (1989). Introdução a uma ciência pós-moderna. [Introduction to PostModern Science]. Rio deJaneiro: Graal.

Teixeira, T. C., Mosquera, J. J. M., \& Stobäus, C. D. (2015). Teachers Tell Us about Full Inclusion. Creative Education, 6, 1044-1052. https://doi.org/10.4236/ce.2015.610103

Trevisan, A. (2006). Hermenêutica da alteridade educative. [Hermeneutics of Educational Alterity]. In: A. L. Trevisan, \& E. M. Tomazetti (Eds.). Cultura e alteridade. [Culture and Otherness] (pp.127-142). Ijuí: Ed. UNIJUÍ.

\section{Scientific Research Publishing}

\section{Submit or recommend next manuscript to SCIRP and we will provide best} service for you:

Accepting pre-submission inquiries through Email, Facebook, LinkedIn, Twitter, etc. A wide selection of journals (inclusive of 9 subjects, more than 200 journals) Providing 24-hour high-quality service

User-friendly online submission system

Fair and swift peer-review system

Efficient typesetting and proofreading procedure

Display of the result of downloads and visits, as well as the number of cited articles

Maximum dissemination of your research work

Submit your manuscript at: http://papersubmission.scirp.org/

Or contact ce@scirp.org 